Article

\title{
Reducing the Nano-Scale Aggregation of Perylene Diimide Based Acceptor by Conjugating a Bridge with a Large Volume
}

\author{
Jun-Yi Chen ${ }^{1, *}, X$-Dong $X^{1 i a}{ }^{1}$ and Jicheng Zhang ${ }^{2}$ (D) \\ 1 College of Life Sciences, Tarim University, Alar 843300, China; xiaxudong_10@163.com \\ 2 Department of Chemistry, University of Washington, Seattle, WA 98195, USA; sdzjc2006@163.com \\ * Correspondence: sln5xn@163.com
}

Received: 2 September 2019; Accepted: 19 September 2019; Published: 24 September 2019

\begin{abstract}
A novel perylene diimide (PDI) based acceptor P-PDI was synthesized by attaching a phenyl bridge to two octyloxy side chains. With two large volume side chains, the planarity of P-PDI was significantly reduced, leading to weak nano-aggregation of the PDI groups between the different acceptor molecules. Differential scanning calorimetry (DSC) experiments also revealed that P-PDI was amorphous, and demonstrating the aggregation of P-PDI was successfully suppressed. When blended with PTB7-Th to fabricate a polymer solar cell, a power conversation efficiency (PCE) of $2.21 \%$ was achieved, demonstrating that a conjugated bridge with a big volume side chain could significantly reduce the nano-scale aggregation of PDI based acceptor materials, which provides a new strategy to synthesize high efficiency acceptors based on PDI.
\end{abstract}

Keywords: perylene diimide (PDI); nano-scale aggregation; non-fullerene; polymer solar cells; large volume side chains

\section{Introduction}

Due to its merits of being flexible, light weight, and having low toxicity, polymer solar cells (PSCs) have attracted attention in the last two decades [1-4]. PSCs usually adopt conjugated polymers as the donor and fullerene derivates such as $\mathrm{PC}_{61} \mathrm{BM}$ or $\mathrm{PC}_{71} \mathrm{BM}$ as the acceptor. Due to the synthesis of novel donor materials and the developing of device fabrication technology, the power conversion efficiency (PCE) has been boosted for single junction PSCs [5]. Although the prospect of PSCs was fascinating, the PCE of PSCs still lagged behind that of inorganic solar cells, which limited their commercial application [6,7]. There are many factors that hamper the increase of PCE in PSCs-one is the weak and narrow absorption of fullerene derivates in the ultraviolet-visible spectroscopy (UV-vis) range, and another one is the difficulty in modifying fullerene based acceptors [8-10]. Aside from this, non fullerene organic acceptors have attracted extensive attention. Organic acceptors not only have wide adsorption in the UV-vis range, but they can supply an easy tuning energy level to reduce the energy loss between the donor and acceptor [11,12]. Recently, a PCE of $16 \%$ for non fullerene acceptor based PSCs was achieved, demonstrating their potential to break through the limitation of fullerene based acceptors [13].

Among the widely investigated non fullerene acceptors, perylene diimide (PDI) based small molecules or polymers have attracted abundant attention because of the merits of high electron mobility [14-16]. Although PDI based small molecules as acceptors were intriguing, the strong aggregation caused by the large planar chemical structure of the PDI units usually affects the exciton separation in the blend films [17]. The general way to solve this problem is to introduce a twisty bridge to create a non planar structure, however the over-twisty structure of PDI based small molecules would also induce inferior electron mobility when blended with donor materials [14]. 
In this contribution, a new polymer acceptor based on PDI (P-PDI) was synthesized by the Suzuki reaction of 2,2'-(2,5-Bis(octyloxy)-1,4-phenylene)bis(4,4,5,5-tetramethyl-1,3,2-dioxaborolane) and 5,12-dibromo-2,9-bis(2-ethylhexyl)anthra[2,1,9-def:6,5,10-d' $\left.\mathrm{e}^{\prime} \mathrm{f}^{\prime}\right]$ diisoquinoline-1,3,8,10(2H,9H)-tetraone (Appendix A.4). By introducing two side chains with a large volume in the phenyl unit, the planarity of the polymer backbones could be reduced and the nano-scale aggregation of PDI between intra molecules was also suppressed because of the big side chains, leading to a more uniform morphology when blended with PTB7-Th. As a result, a PCE of $2.21 \%$ with a voltage of $0.82 \mathrm{~V}$ was achieved, demonstrating that a conjugated bridge with a big volume side chain could significantly reduce the nano-scale aggregation of PDI based acceptor materials.

\section{Results and Discussion}

\subsection{Materials Synthesis and Characterization}

As shown in Scheme 1, P-PDI was synthesized by one step of the Suzuki coupling reaction of compound 1 and 2 using tetrahydrofuran (THF) as the solvent, $\mathrm{NaHCO}_{3}$ as the base, and $\mathrm{Pd}(\mathrm{PPh})_{4}$ as the catalyst procedure. PTB7-Th was also synthesized by the Stille reaction according to the literature [18]. P-PDI can dissolve in common organic solvents such as chloroform $\left(\mathrm{CHCl}_{3}\right)$ and dichlorobenzene (DCB) at room temperature, whereas PTB7-Th could only dissolve in dichlorobenzene (DCB) at an elevated temperature. Measured by gel permeation chromatography (GPC) at a temperature of $150{ }^{\circ} \mathrm{C}$ with 1,2,4-trichlorobenzene (TCB) as the eluent, the average molecular weight $\left(M_{n}\right)$ of PTB7-Th and P-PDI was determined to be 47.1 and $66.8 \mathrm{~kg} / \mathrm{mol}$, respectively. The chemical structure of polymer donor PTB7-Th, acceptors P-PDI and PDI was shown in Scheme 2.

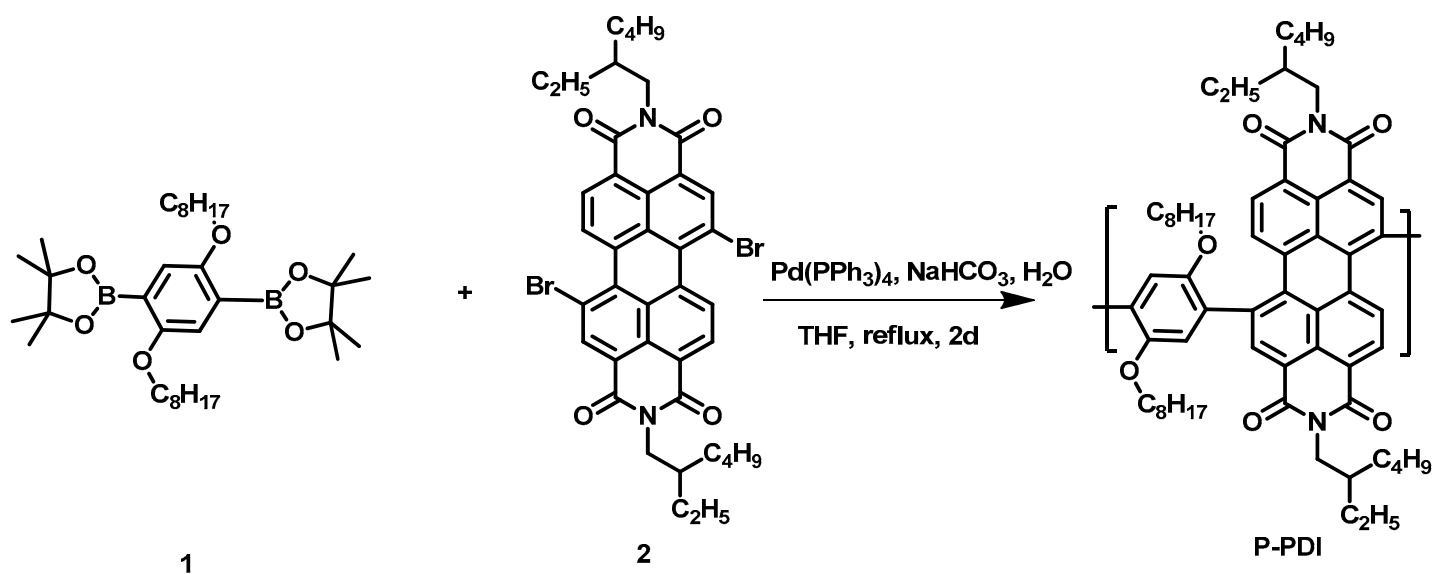

Scheme 1. The synthetic route of the polymer acceptor based on perylene diimide (P-PDI).
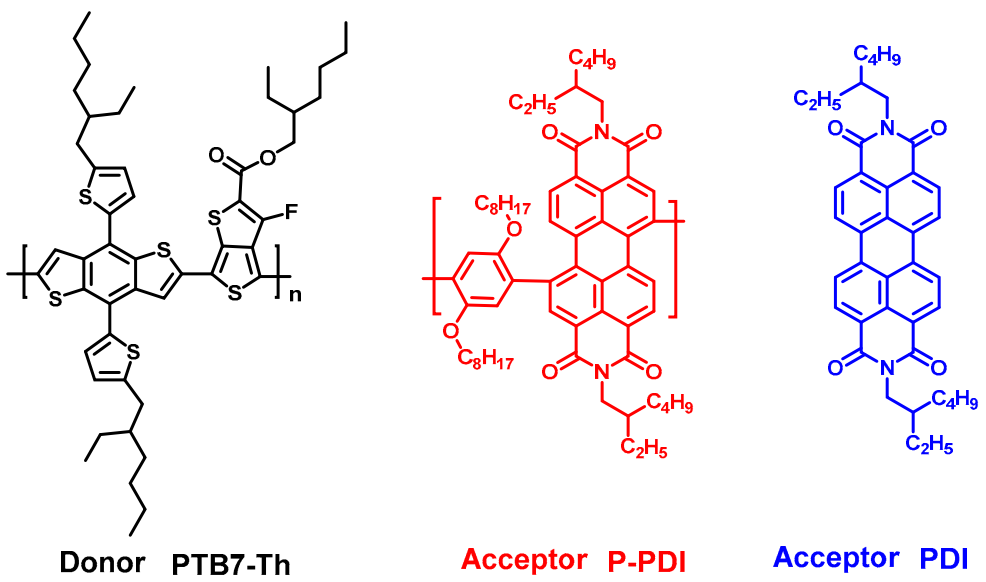

Scheme 2. Chemical structure of polymer donor PTB7-Th and acceptors P-PDI and PDI. 


\subsection{Optical Properties}

To shed light on the light absorption properties of P-PDI, the UV-vis absorption spectra of P-PDI were measured in DCB solutions and as films. As shown in Figure 1a, P-PDI exhibited a broad absorption spectrum in the range from $350 \mathrm{~nm}$ to $650 \mathrm{~nm}$ in solutions, which might be propitious to generate more photocurrent when blended with PTB7-Th. Upon changing from solutions to films, the absorption peaks were red-shifted, demonstrating that the aggregation in the films was not fully suppressed. The onset adsorption of P-PDI as films is $651 \mathrm{~nm}$, corresponding to the optical band gap $\left(E_{\mathrm{g}, \mathrm{opt}}\right)$ value of $1.90 \mathrm{eV}$ using the equation: $E_{\mathrm{g}, \mathrm{opt}}=1240 / \lambda_{\text {onset. }}$

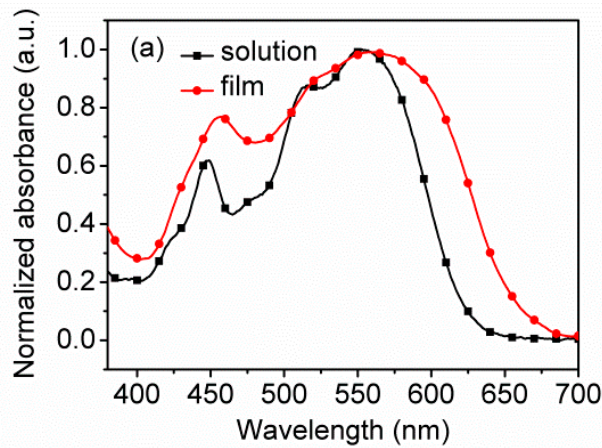

(C)

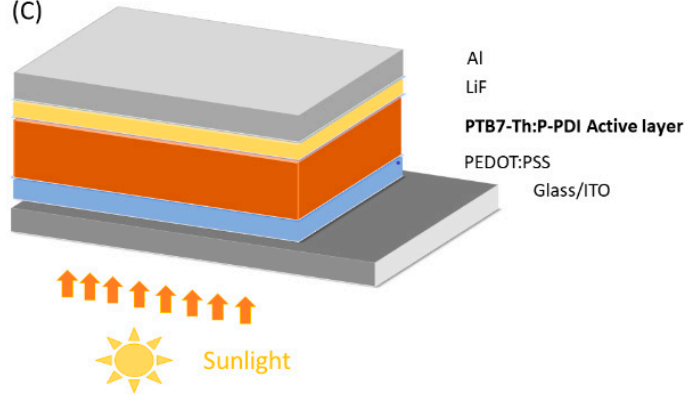

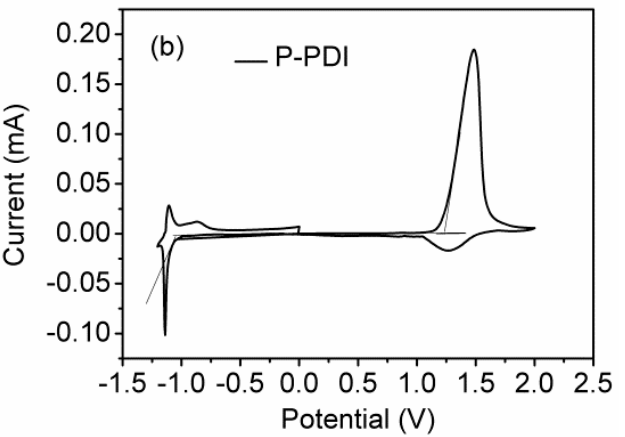

(d)

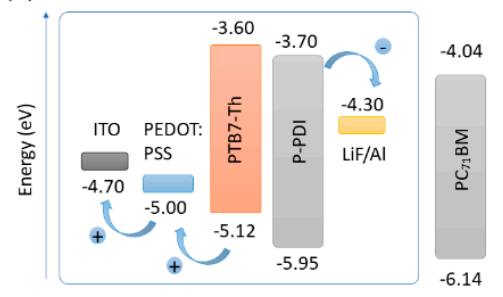

Figure 1. (a) Ultraviolet-visible spectroscopy (UV-vis) absorption spectra of P-PDI in solutions and as films; (b) cyclic voltammetry (CV) curve of P-PDI; (c) Device structure for polymer solar cell (PSC) devices; (d) Molecular orbitals of PTB7-Th:P-PDI and PC ${ }_{71} \mathrm{BM}$.

\subsection{Electrochemical Properties}

To study the electrochemical properties of P-PDI, the cyclic voltammetry (CV) curves of P-PDI films on a glassy carbon working electrode were measured in a $\mathrm{CH}_{3} \mathrm{CN}$ solution $\left(0.1 \mathrm{~mol} / \mathrm{L} \mathrm{Bu}_{4} \mathrm{NPF}_{6}\right)$. As shown in Figure $1 \mathrm{~b}$, the onset oxidation potential of P-PDI was determined to be $1.24 \mathrm{~V}$, and the HOMO energy level of P-PDI was therefore estimated to be $-5.95 \mathrm{eV}$ by the equation of $E_{\mathrm{HOMO}}=-\mathrm{e}\left(E_{\mathrm{ox}}+4.71 \mathrm{~V}\right)$. Similarly, the reduction potential of P-PDI was measured to be $-1.01 \mathrm{~V}$, and the LUMO energy level of P-PDI was therefore estimated to be $-3.70 \mathrm{eV}$ according to the same equation. The electrochemical band gap $\left(E_{\mathrm{g}}\right)$ was then calculated to be $2.25 \mathrm{eV}$ according to the equation $E_{\mathrm{g}}=E_{\mathrm{LUMO}}-E_{\mathrm{HOMO}}$, which is similar to the value of $E_{\mathrm{g}, \mathrm{opt}}$. As shown in Figure 1d, the LUMO level of P-PDI was slightly higher than that of $\mathrm{PC}_{71} \mathrm{BM}$, which might lead to higher $V_{\mathrm{oc}}$ when used as acceptor materials $[19,20]$.

\subsection{Photovoltaic Properties}

To investigate the photovoltaic performance of P-PDI as the acceptor in devices, conventional devices with a configuration of ITO/PEDOT:PSS/PTB7-Th:P-PDI/LiF/Al were fabricated, as shown in Figure 1c. DCB was adopted as the solvent to fully dissolve PTB7-Th and P-PDI at $90^{\circ} \mathrm{C}$. The weight ratio of PTB7-Th:P-PDI and the thickness of the blend films was adjusted to optimize the performance of the devices. After optimization, the highest PCE was achieved with a donor/acceptor ratio of 1:2 
and a film thickness of $102 \mathrm{~nm}$. The current density voltage $(J-V)$ curve of the optimized devices is displayed in Figure 3a and detail parameters are summarized in Table 1. As shown in Figure 2a and Table 1, a PCE of $2.21 \%$ was achieved with a $V_{\mathrm{oc}}$ of $0.82 \mathrm{~V}$, a $J_{\mathrm{sc}}$ of $7.92 \mathrm{~mA} / \mathrm{cm}^{2}$, and an fill factor (FF) of 0.34 , revealing the potential of P-PDI to be used as acceptor materials. The $V_{\text {oc }}$ of P-PDI was slightly higher than that based on $\mathrm{PC}_{71} \mathrm{BM}$, demonstrating that the energy loss between PTB7-Th and acceptors was reduced [19]. The FF of the devices was still not very high, which might be attributed to the unbalanced hole and electron mobilities and the resulting recombination loss in the devices (vide infra) [21]. Besides, the inherent defect of the active layer might also induce some non-geminate recombination like excimers [22], bulk-traps, and surface-traps and may lead to reduced photovoltaic performance [23].
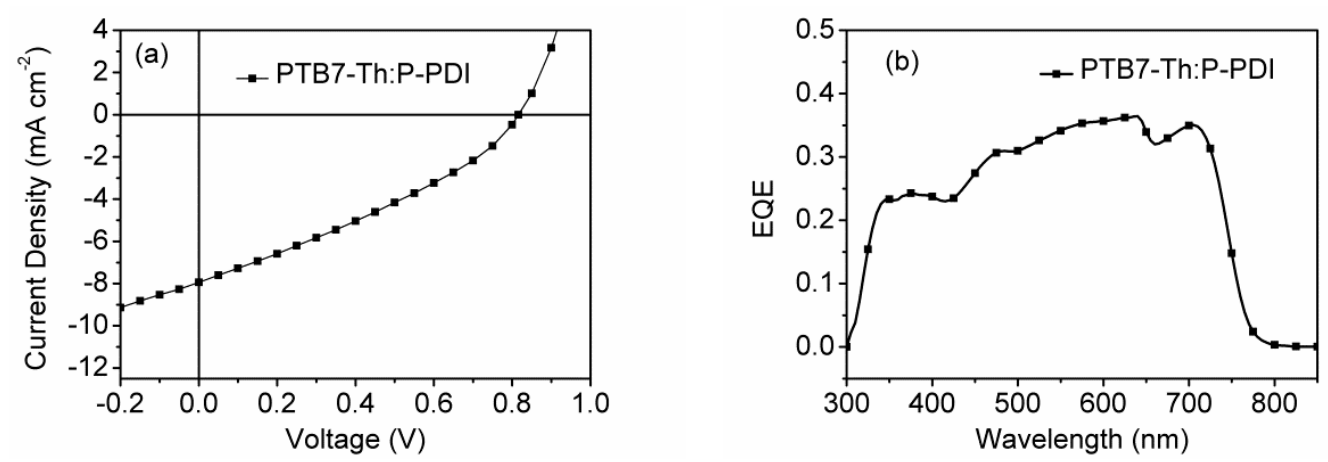

Figure 2. $J-V$ (a) and external quantum efficiency (EQE) (b) curves of PTB7-Th:P-PDI based optimized devices.

Table 1. Summary of the photovoltaic properties of PTB7-Th:P-PDI based devices.

\begin{tabular}{|c|c|c|c|c|c|}
\hline Active Layer & $V_{\text {oc }}(\mathrm{V})$ & $J_{\mathrm{sc}}\left(\mathrm{mA} \cdot \mathrm{cm}^{-2}\right)$ & $F F$ & $\begin{array}{l}\text { Power Conversation Efficiency } \\
\text { (PCE) (\%) Best/Ave }{ }^{a}\end{array}$ & Film Thickness (nm) \\
\hline PTB7-Th:P-PDI & 0.82 & 7.92 & 0.34 & $2.21 / 2.10$ & 102 \\
\hline
\end{tabular}

External quantum efficiency (EQE) experiments of PTB7-Th:P-PDI based optimized devices were also carried out to verify the $J_{\text {sc }}$ of $J-V$ test. As shown in Figure 2b, PTB7-Th:P-PDI display a broad response peak in the range from $300 \mathrm{~nm}$ to $800 \mathrm{~nm}$ with a maximum value of 0.37 at $640 \mathrm{~nm}$, generating more photocurrent in the UV-vis range. The $J_{\mathrm{sc}}$ value integrated from the EQE curves $\left(7.78 \mathrm{~mA} \mathrm{~cm}^{-2}\right)$ agree well with the $J_{\mathrm{sc}}$ value from the $J-V$ experiments, demonstrating that the $J-V$ text results were reliable.

\subsection{Transport Properties}

To shed light on the carrier transport in the devices, a hole only device with a structure of ITO/PEDOT:PSS/PTB7-Th:P-PDI/Au and an electron only device with a structure of FTO/PTB7-Th:P-PDI/Al were constructed. The hole mobility $\left(\mu_{\mathrm{h}}\right)$ of PTB7-Th and electron mobility of P-PDI in the devices was therefore determined, respectively, from the dark $J-V$ curves of these two devices using the space-charge limited current (SCLC) method. The dark $J-V$ curves of these devices were then fitted via the Mott-Guney equation: $J=9 \varepsilon_{0} \varepsilon_{r} \mu V^{2} / 8 L^{3}$, where $\varepsilon_{r}$ is the permittivity of the active layer, $\varepsilon_{o}$ is vacuum permittivity, $\mu$ is the hole mobility or electron mobility, and $L$ is the active layer thickness. As shown in Figure 3, the $\mu_{\mathrm{h}}$ value of the devices with a donor acceptor ratio of 1:2 was calculated to be $4.01 \times 10^{-5} \mathrm{~cm}^{2} \mathrm{~V}^{-1} \mathrm{~s}^{-1}$, whereas the $\mu_{\mathrm{e}}$ value of the devices with a donor acceptor ratio of 1:2 was determined to be $6.41 \times 10^{-6} \mathrm{~cm}^{2} \mathrm{~V}^{-1} \mathrm{~s}^{-1}$, which was two orders of magnitude lower than that of $\mu_{\mathrm{h}}$, resulting in inferior FF. Although the hole mobility and the electron mobility of the devices was not very balanced, the $\mu_{\mathrm{e}}$ of P-PDI was higher than many acceptors [24,25], which could be ascribed to the reduced nano-aggregation of P-PDI. 


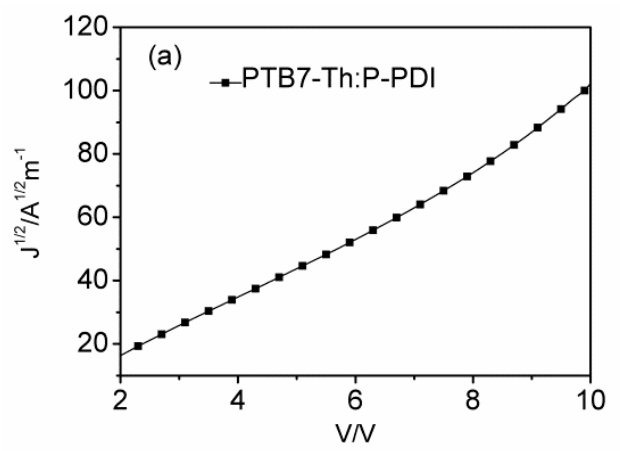

Figure 3. $J^{1 / 2}-\mathrm{V}$ curves for determining the $\mu_{\mathrm{h}}(\mathbf{a})$ and $\mu_{\mathrm{e}}(\mathbf{b})$ curves of PTB7-Th:P-PDI based optimized devices.

\subsection{Film Morphology}

The main obstacle for PDI based accepters was their strong aggregation as films. When blended with polymer donors, large domains usually formed, leading to inferior exciton separation and low PCE in devices $[17,26]$. After conjugating PDI with a linker with a large volume side chain, P-PDI displayed no obvious glass transition peak in the range from $60{ }^{\circ} \mathrm{C}$ to $240{ }^{\circ} \mathrm{C}$ in DSC traces (Figure $4 \mathrm{a}$ ), revealing that P-PDI was amorphous. To shed light on the film morphology of PTB7-Th:P-PDI blend films, atomic force microscopy (AFM) was used in the tapping mode. As shown in Figure 4a, the blend film displays a pretty smooth film with a root mean square (RMS) roughness of $1.21 \mathrm{~nm}$, demonstrating that no significant aggregates of P-PDI were formed in the blend films [27]. To further investigate the inside film morphology of the active layer, scanning electron microscope (SEM) and transmission electron microscopy (TEM) were also adopted. As shown in Figure 4c-f, the domain size in the PTB7-Th:P-PDI active layer was significantly smaller than PTB7-Th:PDI, revealing that the aggregation of P-PDI was significantly reduced by introducing a bridge with large side groups, and a higher PCE was therefore acquired [28].
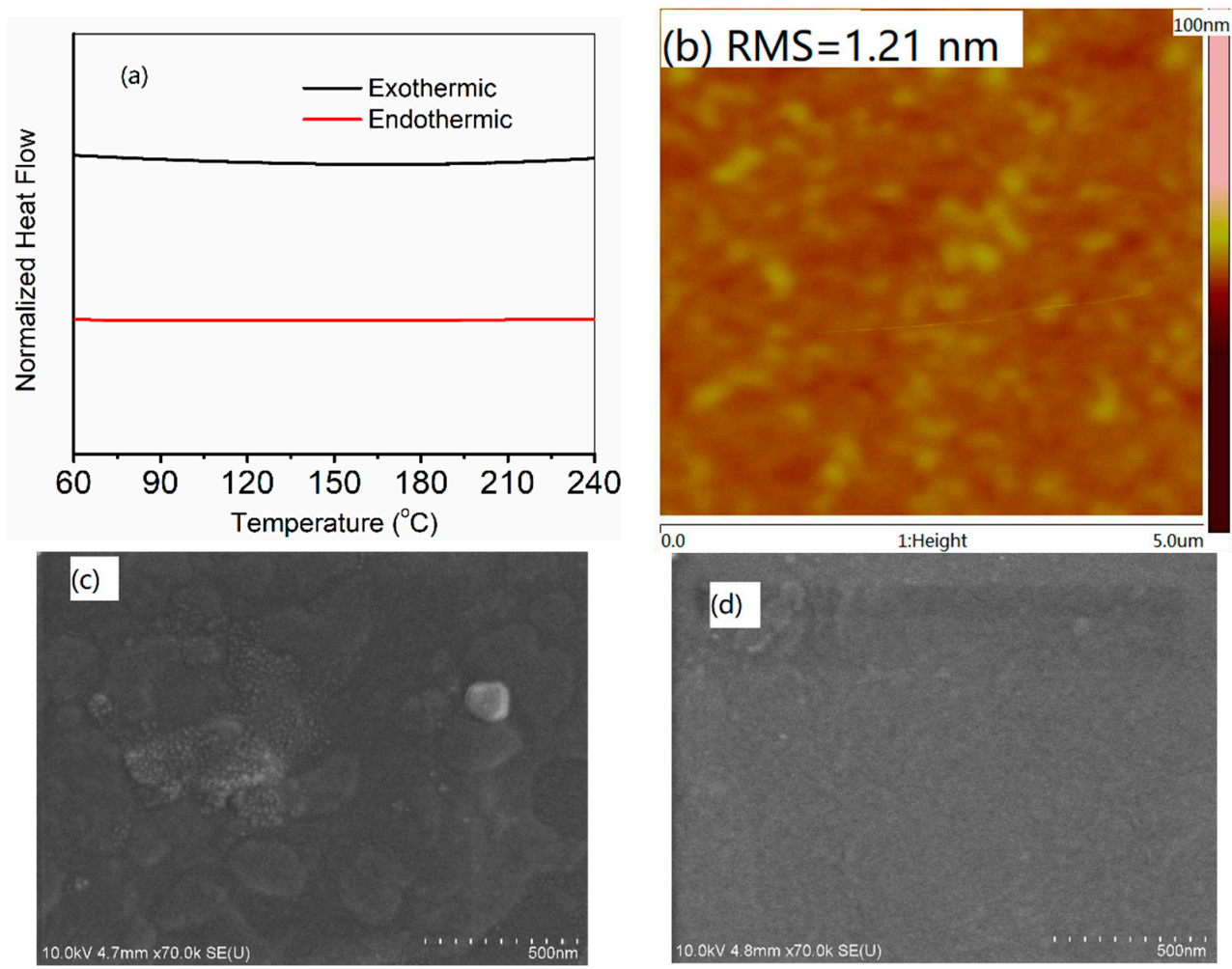

Figure 4. Cont. 

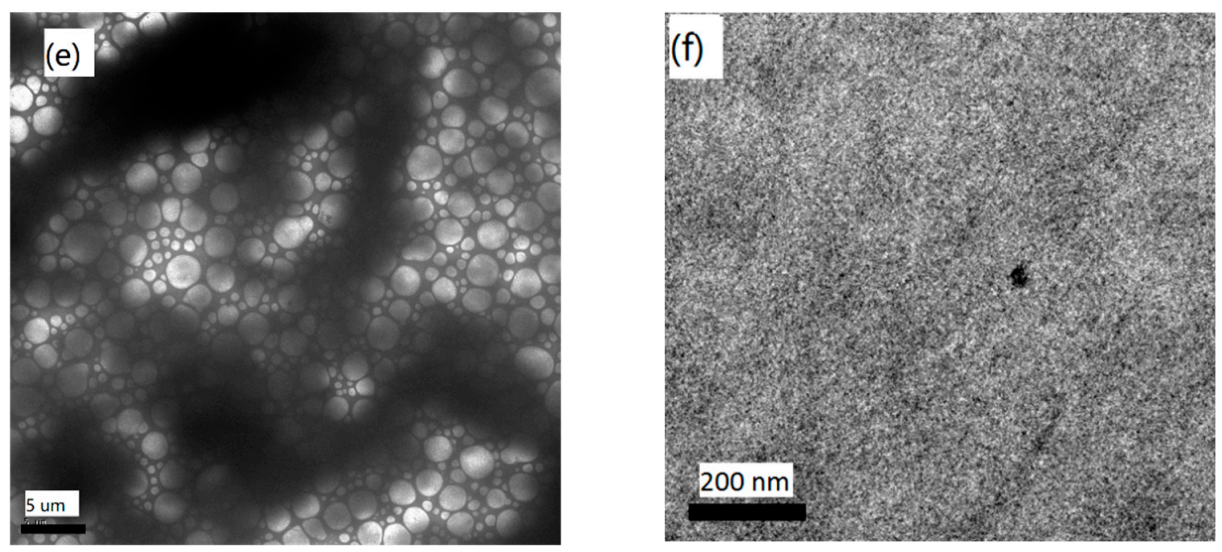

Figure 4. (a) DSC curves of P-PDI; (b) atomic force microscopy (AFM) height images of PTB7-Th:P-PDI blend films; (c) scanning electron microscope (SEM) images of PTB7-Th:PDI blend films (Scale bar: $500 \mathrm{~nm}$ ); (d) SEM images of PTB7-Th:P-PDI blend films (Scale bar: $500 \mathrm{~nm}$ ); (e) transmission electron microscopy (TEM) images of PTB7-Th:PDI blend films (Scale bar: $5 \mu \mathrm{m}$ ) (f) TEM images of PTB7-Th:P-PDI blend films (Scale bar: $200 \mathrm{~nm}$ ).

\section{Conclusions}

In conclusion, a novel PDI based acceptor P-PDI was designed and synthesized. A phenyl unit with two side octyloxy groups was introduced to the polymer backbones to reduce the nano-scale aggregation of the PDI unit. DSC experiments revealed that P-PDI was amorphous, demonstrating that the aggregation of the PDI unit in the acceptors was significantly suppressed. When blended with PTB7-Th to fabricate a non fullerene PSCs, a PCE of $2.21 \%$ with a $V_{\mathrm{oc}}$ of $0.82 \mathrm{~V}$, a $J_{\mathrm{sc}}$ of $7.92 \mathrm{~mA} / \mathrm{cm}^{2}$, and an FF of 0.34 was acquired. AFM and TEM of the blend films also displayed rather smooth film morphology, revealing that conjugating a bridge with a large volume could effectively reduce the nano-aggregation of PDI based acceptors. Our results also indicated that P-PDI is a potential acceptor for non fullerene PSCs.

Author Contributions: Conceptualization, J.-Y.C.; Methodology, J.-Y.C.; Software, X.-D.X.; Validation, J.-Y.C. and X.-D.X.; Formal Analysis, J.-Y.C.; Investigation, J.-Y.C.; Resources, X.-D.X.; Data Curation, J.-Y.C.; Writing-Original Draft Preparation, J.-Y.C.; Writing-Review \& Editing, J.Z.; Visualization, J.-Y.C.; Supervision, J.Z.; Project Administration, J.-Y.C.; Funding Acquisition, J.-Y.C.

Funding: This work was supported by the Principal Fund project of Tarim University (TDZKJC201603).

Acknowledgments: Authors thank for Jun Zhou in Northeastern University to help do the photovoltaic experiments and other test.

Conflicts of Interest: The authors declare no conflict of interest.

\section{Appendix A. Experiment Part}

Appendix A.1. Materials

All chemicals were purchased from commercial sources and used without further purification. Solvents were purified by the standard techniques. 2,2'-(2,5-Bis(octyloxy)-1,4-phenylene)bis(4,4,5,5tetramethyl-1,3,2-dioxaborolane) (1) and 5,12-dibromo-2,9-bis(2-ethylhexyl)anthra[2,1,9-def:6,5,10$\mathrm{d}^{\prime} \mathrm{e}^{\prime} \mathrm{f}^{\prime}$ ]diisoquinoline-1,3,8,10(2H,9H)-tetraone (2) were synthesized according to the previous literature. Polymer donor PTB7-Th was also achieved by the literature reported [18].

\section{Appendix A.2. Polymer Solar Cells Fabrication and Characterization}

PSCs were fabricated with the device configuration of ITO/PEDOT:PSS (35 nm)/ PTB7-Th:P-PDI/LiF $(0.7 \mathrm{~nm}) / \mathrm{Al}(100 \mathrm{~nm})$. The conductivity of ITO is $15 \Omega$. PEDOT:PSS (Baytron Al 4083 from H.C. Starck) and was filtered with a $0.45 \mathrm{~mm}$ polyvinylidenedifluoride (PVDF) film before use. A PEDOT:PSS thin 
layer was spin-coated on top of the cleaned ITO substrate at $3000 \mathrm{rpm} / \mathrm{s}$ for $50 \mathrm{~s}$ and was dried at $130{ }^{\circ} \mathrm{C}$ for $20 \mathrm{~min}$ on a hotplate. A mixture of PTB7-Th and P-PDI in 1,2-dichlorobenzene (DCB) was stirred at $90{ }^{\circ} \mathrm{C}$ overnight to ensure sufficient dissolution, and the blend solution was spin-coated onto the substrates with a temperature of $90^{\circ} \mathrm{C}$ to form the active layer. The weight concentrations of the blend of PTB7-Th and P-PDI were $25 \mathrm{mg} / \mathrm{mL}$. A top electrode of $0.7 \mathrm{~nm} \mathrm{LiF}$ and $100 \mathrm{~nm}$ of aluminium were thermally evaporated at a pressure of $10^{-4} \mathrm{~Pa}$ through a shadow mask. On one substrate, five cells with an effective area of $0.04 \mathrm{~cm}^{2}$ each were fabricated. Current-voltage (I-V) and external quantum efficiency (EQE) measurements were conducted in air without encapsulation. The I-V characteristics were recorded at room temperature using an Agilent B2902A Source Meter under the illumination of an AM1.5G AAA class solar simulator (model XES-301S, SAN-EI) with an intensity of $100 \mathrm{~mW} \mathrm{~cm}^{-2}$, and the white light intensity was calibrated with a standard single-crystal Si solar cell.

\section{Appendix A.3. Space-Charge Limited Current Measurement}

Hole-only devices with a structure of ITO/PEDOT:PSS (35 nm)/PTB7-Th:P-PDI/Au (100 nm) and electron-only devices with a configuration of FTO/ PTB7-Th:P-PDI/Al (100 nm) were fabricated. The blend solution of PTB7-Th and P-PDI in DCB was spin-coated onto the PEDOT:PSS layer to form the active layer, like PSC devices, and $100 \mathrm{~nm}$ of Au was thermally evaporated at a pressure of $10^{-4} \mathrm{~Pa}$ through a shadow mask. For the electron-only devices, the blend solution of PTB7-Th and P-PDI in DCB was spin-coated on the clean FTO substrates to form an active layer. Al electrodes (100 nm) were vacuum-deposited on the polymer thin films. Dark $J-V$ curves of the hole-only devices and electron-only devices were measured by the space-charge limited current (SCLC) method.

Appendix A.4. The Synthesis Route of P-PDI

A mixture of compound 1 (234 mg, $0.40 \mathrm{mmol})$, compound 2 (309 mg, $0.40 \mathrm{mmol}), \mathrm{NaHCO}_{3}(0.84 \mathrm{~g}$, $10.0 \mathrm{mmol}), \mathrm{THF}(10 \mathrm{~mL})$, and $\mathrm{H}_{2} \mathrm{O}(2.5 \mathrm{~mL})$ was carefully degassed with $\mathrm{N}_{2}$ before and after $5.8 \mathrm{mg}$ $\mathrm{Pd}\left(\mathrm{PPh}_{3}\right)_{4}$ was added. The mixture was heated to $90^{\circ} \mathrm{C}$ and stirred for 2 days under $\mathrm{N}_{2}$ protection. After the reaction, $15.0 \mathrm{mg}$ phenylboronic acid and $0.30 \mathrm{~mL}$ bromobenzene were added successively to end cap the end groups. Then, the mixture was poured into $100 \mathrm{~mL}$ acetone and collected by filtration. The precipitates were subsequently washed on Soxhlet apparatus by methanol, petroleum ether, and $\mathrm{CHCl}_{3}$, respectively. The component dissolved in $\mathrm{CHCl}_{3}$ was finally precipitated in methanol and dried under vacuum to afford P-PDI as a dark blue solid (246 mg, 64\%). ${ }^{1} \mathrm{H} \mathrm{NMR}(400 \mathrm{MHz}$, 1,2-dichlorobenzene- $\left.\mathrm{d}_{4}\right): \delta(\mathrm{ppm}) 8.93(\mathrm{~m}, 2 \mathrm{H}), 8.78(\mathrm{~m}, 2 \mathrm{H}), 8.36(\mathrm{~m}, 2 \mathrm{H}), 7.98(\mathrm{~m}, 2 \mathrm{H}), 4.30(\mathrm{~m}, 4 \mathrm{H})$, 0.85-2.24 (m, 70H). GPC (PS standards): $M_{\mathrm{w}}=93.1 \mathrm{~kg} \mathrm{~mol}^{-1}, M_{\mathrm{n}}=66.8 \mathrm{~kg} \mathrm{~mol}^{-1}$, and PDI $=1.39$.

\section{References}

1. Thompson, B.C.; Fréchet, J.M. Organic photovoltaics-Polymer-fullerene composite solar cells. Angew. Chem. Int. Ed. 2008, 47, 58-77. [CrossRef] [PubMed]

2. Park, S.H.; Roy, A.; Beaupré, S.; Cho, S.; Coates, N.; Moon, J.S.; Heeger, A.J. Bulk heterojunction solar cells with internal quantum efficiency approaching 100\%. Nat. Photonics 2009, 3, 297. [CrossRef]

3. Günes, S.; Neugebauer, H.; Sariciftci, N.S. Conjugated polymer-based organic solar cells. Chem. Rev. 2007, 107, 1324-1338. [CrossRef] [PubMed]

4. Brabec, C.J.; Sariciftci, N.S.; Hummelen, J.C. Plastic solar cells. Adv. Funct. Mater. 2001, 11, 15-26. [CrossRef]

5. Zhao, J.; Li, Y.; Yang, G.; Jiang, K.; Lin, H.; Ade, H.; Yan, H. Efficient organic solar cells processed from hydrocarbon solvents. Nat. Energy 2016, 1, 15027. [CrossRef]

6. Lee, M.M.; Teuscher, J.; Miyasaka, T.; Murakami, T.N.; Snaith, H.J. Efficient Hybrid Solar Cells Based on Meso-Superstructured Organometal Halide Perovskites. Science 2012, 338, 643-647. [CrossRef]

7. Burschka, J.; Pellet, N.; Moon, S.J.; Humphry-Baker, R.; Gao, P.; Nazeeruddin, M.K.; Grätzel, M. Sequential deposition as a route to high-performance perovskite-sensitized solar cells. Nature 2013, 499, 316. [CrossRef] [PubMed]

8. Lin, Y.; Zhan, X. Non-fullerene acceptors for organic photovoltaics: An emerging horizon. Mater. Horiz. 2014, 1, 470-488. [CrossRef] 
9. Facchetti, A. Polymer donor-polymer acceptor (all-polymer) solar cells. Mater. Today 2013, 16, $123-132$. [CrossRef]

10. Nielsen, C.B.; Holliday, S.; Chen, H.-Y.; Cryer, S.J.; McCulloch, I. Non-fullerene electron acceptors for use in organic solar cells. Acc. Chem. Res. 2015, 48, 2803-2812. [CrossRef]

11. Chochos, C.L.; Tagmatarchis, N.; Gregoriou, V.G. Rational design on n-type organic materials for high performance organic photovoltaics. RSC Adv. 2013, 3, 7160-7181. [CrossRef]

12. McAfee, S.M.; Topple, J.M.; Hill, I.G.; Welch, G.C. Key components to the recent performance increases of solution processed non-fullerene small molecule acceptors. J. Mater. Chem. A 2015, 3, 16393-16408. [CrossRef]

13. Cui, Y.; Yao, H.; Zhang, J.; Zhang, T.; Wang, Y.; Hong, L.; Xian, K.; Xu, B.; Zhang, S.; Peng, J.; et al. Over 16\% efficiency organic photovoltaic cells enabled by a chlorinated acceptor with increased open-circuit voltages. Nat. Commun. 2019, 10, 2515. [CrossRef] [PubMed]

14. Zhong, H.; Wu, C.H.; Li, C.Z.; Carpenter, J.; Chueh, C.C.; Chen, J.Y.; Ade, H.; Jen, A.K.Y. Rigidifying Nonplanar Perylene Diimides by Ring Fusion Toward Geometry-Tunable Acceptors for High-Performance Fullerene-Free Solar Cells. Adv. Mater. 2016, 28, 951-958. [CrossRef] [PubMed]

15. Zhang, X.; Yao, J.; Zhan, C. A selenophenyl bridged perylene diimide dimer as an efficient solution-processable small molecule acceptor. Chem. Commun. 2015, 51, 1058-1061. [CrossRef] [PubMed]

16. Wu, C.H.; Chueh, C.C.; Xi, Y.Y.; Zhong, H.L.; Gao, G.P.; Wang, Z.H.; Pozzo, L.D.; Wen, T.C.; Jen, A.K.Y. Influence of Molecular Geometry of Perylene Diimide Dimers and Polymers on Bulk Heterojunction Morphology Toward High-Performance Nonfullerene Polymer Solar Cells. Adv. Funct. Mater. 2015, 25, 5326-5332. [CrossRef]

17. Lin, Y.; Wang, Y.; Wang, J.; Hou, J.; Li, Y.; Zhu, D.; Zhan, X. A Star-Shaped Perylene Diimide Electron Acceptor for High-Performance Organic Solar Cells. Adv. Mater. 2014, 26, 5137-5142. [CrossRef] [PubMed]

18. Liao, S.; Jhuo, H.; Cheng, Y.; Chen, S. Fullerene Derivative-Doped Zinc Oxide Nanofilm as the Cathode of Inverted Polymer Solar Cells with Low-Bandgap Polymer (PTB7-Th) for High Performance. Adv. Mater. 2013, 25, 4766-4771. [CrossRef]

19. Zhang, J.; Zhang, X.; Xiao, H.; Li, G.; Liu, Y.; Li, C.; Huang, H.; Chen, X.; Bo, Z. 1,8-Naphthalimide Based Planar Small Molecular Acceptor for Organic Solar Cells. ACS Appl. Mater. Interfaces 2016, 8, 5475-5483. [CrossRef]

20. Zhang, J.; Zhang, X.; Li, G.; Xiao, H.; Li, W.; Xie, S.; Li, C.; Bo, Z. A nonfullerene acceptor for wide band gap polymer based organic solar cells. Chem. Commun. 2016, 52, 469-472. [CrossRef]

21. Qi, B.; Wang, J. Fill factor in organic solar cells. Phys. Chem. Chem. Phys. 2013, 15, 8972-8982. [CrossRef]

22. Vollbrecht, J. Excimers in organic electronics. N. J. Chem. 2018, 42, 11249-11254. [CrossRef]

23. Vollbrecht, J.; Brus, V.; Ko, S.; Lee, J.; Karki, A.; Cao, D.; Cho, K.; Bazam, G.; Nguyen, T. Quantifying the Nongeminate Recombination Dynamics in Nonfullerene Bulk Heterojunction Organic Solar Cells. Adv. Energy Mater. 2019, 9, 1901438. [CrossRef]

24. Kwon, O.K.; Park, J.-H.; Park, S.K.; Park, S.Y. Soluble Dicyanodistyrylbenzene-Based Non-Fullerene Electron Acceptors with Optimized Aggregation Behavior for High-Efficiency Organic Solar Cells. Adv. Energy Mater. 2015, 5, 1400929. [CrossRef]

25. Chen, Y.; Tang, A.; Zhang, X.; Lu, Z.; Huang, J.; Zhan, C.; Yao, J. A new solution-processed diketopyrrolopyrrole donor for non-fullerene small-molecule solar cells. J. Mater. Chem. A 2014, 2, 1869-1876. [CrossRef]

26. Lin, Y.; Wang, J.; Zhang, Z.G.; Bai, H.; Li, Y.; Zhu, D.; Zhan, X. An electron acceptor challenging fullerenes for efficient polymer solar cells. Adv. Mater. 2015, 27, 1170-1174. [CrossRef]

27. Zhang, X.; Zhang, J.; Lu, H.; Wu, J.; Li, G.; Li, C.; Li, S.; Bo, Z. 1,8-Naphthalimide based small molecular acceptor for polymer solar cells with high open circuit voltage. J. Mater. Chem. C 2015, 3, 6979-6985. [CrossRef]

28. Lu, Z.; Jiang, B.; Zhang, X.; Tang, A.; Chen, L.; Zhan, C.; Yao, J. Perylene-Diimide Based Non-Fullerene Solar Cells with 4.34\% Efficiency through Engineering Surface Donor/Acceptor Compositions. Chem. Mater. 2014, 26, 2907-2914. [CrossRef]

(C) 2019 by the authors. Licensee MDPI, Basel, Switzerland. This article is an open access article distributed under the terms and conditions of the Creative Commons Attribution (CC BY) license (http://creativecommons.org/licenses/by/4.0/). 